Łukasz Byrski

Jagiellonian University

Krakow, Poland

Faculty of Philosophy

Institute for the Study of Religions
316.72:7.032(38)

https://doi.org/10.18485/climb.2017.5.1.ch11

\title{
ANCIENT SCIENCE: UNDERSTANDING OF THE HISTORY AND LANGUAGE IN ANCIENT CIVILIZATIONS
}

\section{Summary}

When thinking about scientific knowledge in the ancient times we usually tend to dismiss it as a real "science" because of lack of modern methodology in it. Surprisingly for today's society some of the early complex cultures were not so far from our in seeking the knowledge and understanding of their own history and language and manipulate them for a purpose. Sometimes they even created "scientific disciplines" very close to modern classifications but with very different and unexpected for us goals set before them. In Mesopotamia Akkadians who inherited written culture from Sumerians were facing probably for the first time in human history the problem of translating from completely different language compiling first dictionaries and looking into the differences between their own words and those of other people. Ancient Chinese wondered about the origin of written signs and old objects found accidentally during some ground works. Even more some of them falsified these artefacts to sold it to unknowing collectors. Ancient Egyptians were doing systematic restorations of monuments of the ancestors and preserving written texts. This paper will examine what all that tells us about those cultures, how these "sciences" influenced them and how this interaction is different in modern culture.

Keywords: ancient, Mesopotamia, China, Egypt, history, filology, archaeology, falsifaction, restoration, science

\section{Egypt}

Ancient Egyptians were very interested in preserving their own past and it is well known fact that many monuments underwent restorations 
in the very period. Especially pyramids and the Great Spinx in Gizah was considered as important. Egyptian history know at least few important figures who would be now called "archaeologists". One of them was the Crown Prince, son of the Ramesses II and the high priest of Ptah - Khaemwaset (c. 1284-1224 BCE) who left inscriptions on each object he restored. Of greatest importance is the text from the statue of Prince Kawab, son of pharaoh Khufu (Kheops), who was living one thousand years earlier. There are both stated the context of particular restoration and explicitly given the reason for all these actions:

Khaemwaset, king's son, sem-priest, and the greatest of directors of craftsmen, who was happy because this statue of Kawab, once doomed to turn into rubble[?] in the ... of his father Khufu, had survived intact[?]. [...]because he [Khaemwaset] so loved those sublime ancient ones, who came before, and the excellence of their works - as a matter true a million times (Gomaà 1973:68; Miller, Louis 2012:61).

Another person involved in such endeavor a bit earlier was pharaoh Thutmose IV (c. 1400-1390 BCE or 1388-1379 BCE) who is said to have a dream in which the mysterious Great Sphinx from Gizah revealed himself and told about his problem:

Behold thou me! See thou me! my son Thutmose. I am thy father, Harmakhis-Khepri-Ra-Atum, who will give to thee my kingdom loon earth at the head of the living. [...]

Thou shalt be to me a protector (for) my manner is as I were ailing in all my limbs. The sand of this desert upon which I am, has reached me; turn to me, to have that done which I have desired, knowing that thou art my son, my protector. (Breasted 1906:323325).

These words were written on the so called "Dream Stele" or "Sphinx Stele of Thutmose IV" which is placed between statue's paws. The Sphinx - who present himself as the Egyptian sun god in all his forms (Khepri, Ra and Atum) who is also creator god (Atum) and address the future ruler as his father - has his limbs covered with sand and ask for help in digging him out. The inscription serves both for legitimization of power of the ruler - who had rivals to the throne - as Sphinx-sun god promise him kingship in return for saving him and is on the other hand a memorial and legitimization of king's efforts to remove sand from the great monument 
built by the ancestors (Schneider 2001:347). The story itself is a variation on the motive of the sun god fighting with the forces of chaos personified by the sands of desert (Pinch 2002:207). The next important source is the "Boundary Stele S" located on the south-east border of the Akhetaten ruins. This type of monument was set as the indicator of city borders. The inscription left there by the pharaoh Akhenaten say in the end:

It shall not be erased. It shall not be washed out. It shall not be hacket out. It shall not be covered with gypsum. It shall not be made to disappear. If it disappears, if it vanishes, if the stele $(w \underline{d})$ on which it is falls down. I shall renew it again, afresh in this place in which it is. (Wilson 2001:60; Lichtheim 1976:51; Byrski 2012:25)

The word for a stele that can be found here as in many other texts is $w \underline{d}$ (uđ) which is one of the readings of the hieroglyph 026 in the Gardiner's catalogue representing stone slab. The word can mean "stone monument", "border stone", "decree", “inscription" etc. (Gardiner 1973:495; Vygus 2012:651, 1988, 1990, 1992). The second reading is ' $h$ ' (aha) or "hi w (ahau) with a meaning: "post", "stand", "wait" suggesting object set as a memorial (Gardiner 1973:495; Vygus 2012:1483-1484). In the first case "decree" was understood as something that is officially issued by the king and therefore has the special power unlike usual inscription (Byrski 2014:31). This is the reason for appearing of the very unusual type of inscriptions that are called "pseudoepigraphs" by the Egyptologists. They are encountered in the Late Period (I millennium BCE) and try to convince the reader that they were made centuries before presenting the events and contents as real and using archaic language. One of them supposedly describing the actions that took place during Ramesses II rule (12791213 BCE) was found in the temple of god Khonsu in Karnak and is known now as the "Bentresh Stele" (Markiewicz 2005:198). The text tell the story about Ramesses II quest to the land of Nahrin (Mitanni) where he received tribute from the other rulers and one of them gave him his daughter as wife. She become queen Neferure afterwards. Soon messenger came from this land - which was called Bakhtan in the inscription - asking for help for the sick Bentresh - sister of the Egyptian queen. Pharaoh send the wise scribe who is proficient in medical knowledge but he cannot help her recognizing that she is possessed by the evil spirit. Ramesses turns - as a last resort - to the Theban god Khonsu who agree to travel to Bakhtan and 
cure Bentresh. But the ruler of this country seeing the miracles done by the statue of Khonsu intend to keep it. After a few years Khonsu change into golden Horus and want to fly back to Egypt what terrify ruler of Bakhtan so he agree to let him go providing the gifts for his temple.

The story is fictional because of few facts that are known from other sources: 1) Ramesses II never reached the region described in the text (Syria) as did some of the other pharaohs of the New Kingdom, 2 ) he in fact married Asian princess and her name was Maatneferure but she was daughter of the Hittite king (Lichtheim 1980:93). The inscription was created during Persian or Ptolemaic rule and is designed as document raising the rank of the god Khonsu and his priests (Markiewicz 2005:199). Some scholar are going further and suggest that the text has hidden message stating that Egyptian gods always repel evil foreign spirits (Lichtheim 1980:90; Markiewicz 2005:199).

Other "pseudoepigraph" is the so called "Famine Stele" which is carved on rock located on Sehel island next to the 1st Nile cataract. It goes back in time even further claiming to be the decree of the Old Kingdom pharaoh Djoser (c. 2720-2700 BCE) of the $3^{\text {rd }}$ Dynasty. In the inscription king gives his relation of the events that took place in Egypt - 7 years of drought and its consequences and also how he turns to god Khnum for help. The god give him answer in a dream in a very similar manner to the previously mentioned "Dream Stele". In end of the text Djoser gives an order to renew temple of Khnum and grant the priest of this god with privilege of collecting tribute from the land south to Elephantine island. Characteristically for all the decrees the inscription last sentence is an order to carve the whole text in stele for sanctuary and made duplicate on a tablet so it would exist in double copies.

Again it is a story made up by priests, this time of Khnum, who try to legitimate their privileges as given by a great ancient king because of competition with the centre of the Isis cult on the Philae island (Markiewicz 2005:200). However it is worth noting that there are scholars who believe that it can be copy of the Old Kingdom inscription (Markiewicz 2005:200).

The third candidate for the category of "pseudoepigraphs" is so called "Monument of Memphite Theology" better known as "Shabaka 
Stone". The inscription itself say that it was ordered by pharaoh Shabaka of the $25^{\text {th }}$ Dynasty (c. 716-702 BCE) and modern scholars dated it for around year 710 BCE. But as with all "pseudoepigraphs" it claims to be copy made from the ancient scroll "eaten by worms" and considered so important by the king that he put it in stone so it would survive (Markiewicz 2005:200). The text is written in archaic language similarly to other from the same genre. Interestingly it resembles the language of the "Pyramid Texts" - the oldest religious literature that we know of (Lichtheim 1973:51). There is great debate about the character of "Memphite Theology". Some the contents could even exist during $3^{\text {rd }}$ Dynasty (c. 2740-2670 BCE) but definitely were not created after New Kingdom period (c. 15391075 BCE) (Bator 2012:317-319 \& footnote 262; Bodine 2009:9-11) . Kurt Sethe and Hermann Junker both saw in the inscription some elements of ancient Egyptian drama play (Lichtheim 1973:51). If we look into content of "Shabaka Stone" it is clear that it serves as a hymn to Ptah who is here depicted as the main divinity, creator of the world, and all the other gods are just his forms. This suggest that the inscription was created for the purposes of priests of Memphite Ptah and could be "pseudoepigraph" after all (Markiewicz 2005:201).

Endevours to preserve the past and memory of the long forgotten dead people appear even in popular ancient Egyptian stories from the genre of historical fiction as is it is the case with the late New Kingdom - Ramesside Period (1186-1077 BCE) one known today as "Khonsemhab and the Ghost" (Manassa 2013:18).

\section{Mesopotamia}

In ancient Mesopotamia probably any philological interests began with establishing the institution of education, where people were taught how to write. As a part of this training it was necessary to copy words into the lists of related terms. As Sumerian language was of agglutinative type - which means that to unchangeable root were added suffixes modifying the basic word - exercises of this kind were helpful to remember signs (Walker 1990:25). The lists not only included spellings of similar words but also classification to groups by categories like: stone objects, wood- 
en objects, reed objects, names of gods, human activities. The oldest examples of this kind of so called "lexical lists" comes from Uruk IV period (ca. 3300 - 3100 BCE). Later on things got more complicated when Akkadians become dominant people in Mesopotamia but were continuing civilization started by Sumerians. It was the moment when for the scribes it become necessary to learn how to write in both languages and there was no other way to do it than preparing Sumero-Akkadian lexical lists - that today might be called first dictionaries. Those lists of things were stored together with literary works and administrative inscriptions in archives. It was typical feature for Mesopotamian city-state to establish institution being a kind of "national archive”, that collect and keep all those texts. But there were private libraries as well. Especially for the Old Babylonian period there are many of them, sometimes of significant size like one in Tell ed-Der that was holding around 3000 cuneiform tablets (ca. 1635 BCE) (Walker 1990:48). Of very important fact is that the texts were kept on shelves like in modern libraries but sometimes in baskets or jars to which were attached special tags naming the category of texts. In epic of NaramSin there is mentioning of that custom: "Open the box with tablets and read the stele" (Walker 1990:49). What is also important - titles of texts were written on the side of tablet to help librarian to identify the right tablet, sometimes additionally the first line of next tablet was written in colophon of previous one (as for example story of flood in Gilgamesh: „He, Who Saw Everything, tablet eleven”) (Walker 1990:49).

Of many libraries of cuneiform tablets found by the archaeologists one is very special. It was located in Assyrian capital of Nineveh and built by the great scholar-king Assurbanipal in $7^{\text {th }}$ century BCE. According to estimates it stored around 5000 works on around 30000 cuneiform tablets that were copies or brought by the royal scribes who were following king's order (Drewnowska-Rymarz, Wygnańska 2007:103).

Hunt for the valuable tablets which are in your archives and which do not exist in Assyria and send them to me. I have written to the officials and overseers... and no one shall withhold a tablet from you; and when you see any tablet or ritual about which I have not written to you, but which you perceive may be profitable for my palace, seek it out, pick it up, and send it to me (Nemet-Nejat 1998:63).

The king Assurbanipal (668-ca. 627 BCE) always liked to present himself as a great scholar and wise ruler and in one text he present himself: 
Култура и/или наука

I (Assurbanipal) studied the secret knowledge, the entire scribal craft: the work of wise Adapa. [...] I have read the artfully written text whose Sumerian version is arcane, and the Akkadian difficult to clarify. I have examined the inscriptions of stone before the flood, that abstruse esoteric composition (Beaulieu 1994:38; Miller, Louis 2012:69).

But Assurbanipal and Assyrians in general weren't the only ones interested in antiquities in history of Mesopotamia. One of the earliest account of search for objects of the past in ancient Middle East comes from the tablet kept currently in the British Museum in London but with sure provenience from city of Sippar. The tablet inscription dated to preSargonic period (2650-2340 BCE) say that it was in: "the right shoulder of a stone statue which ... on the debris of the E-babbar" (Miller, Louis 2012:68).

The most extent scale of "excavations" were done during Neo-Babylonian period (626-539 BCE) when it became state policy to find the wisdom of the great predecessors especially in the time of need for tradition as the base of cultural independence when Babylonia just liberated itself from Assyrian Empire (Miller, Louis 2012:69-70). This can be seen from the inscription left by king Nabonidus (556-539 BCE):

Because for a very long time the office of the high priestess had been forgotten and her characteristic features were nowhere indicated, I betought myself day after day. [...]

Indeed I set eyes on an ancient stele of Nebuchadnezzar, [...] an early king of the past, On which was depicted the image of the high priestess; [...]

And did exactly as in the olden days, A stele, her appartenances, and her household equipment I fashioned anew, respectively inscribed on it, And deposited it before my lord and lady Sin and Ningal (Reiner 1985:3; Miller, Louis 2012:69-70).

The reason for those "excavations" was also to dig out the heart of the great building - temple or palace - that was called temenu which is usually foundation brick or stone bearing inscription of the builder. It worked as a beacon of where the building was so it could be rebuild by future kings because there was not enough stone material to erect more durable constructions (Miller, Louis 2012:65-67). 


\section{Culture and/or Science}

The different case was with inscriptions themselves. The earliest monumental inscriptions in Mesopotamia make their appearance in the so called Pre-Sargonic times (2650-2340 BCE) - a part of wider period known as Old Sumerian or Early Dynastic (ca. 2800-2340 BCE) - and usually are foundation texts of votive character carved on bricks or stone hinges (Mierzejewski 1979:132). From the same time also the first steles are known - like the one set under the order of king Eannatum of Lagash which is now called "Stele of the Vultures" and is the earliest in line in the subgenre of inscriptions with historical content (Mierzejewski 1979:134). It retells the story of conflict between two city-states: Umma and Lagash and was set around the year 2525 BCE to commemorate victory of the army of latter lead by the king Eannatum (Nardo 2007:272). The most interesting and relevant for later written culture of Mesopotamia is the fact that the whole reason for "the war" between city-states was border quarrel over 1 channel and 1 cultivated field - which is mentioned in the inscription itself - but what also means that "armies" were of very few warriors and despite all of that the event was presented as the great battle on the monument made of stone which was very rare and expensive raw material in the area of Sumer (Mierzejewski 1983:82). It is most likely that there were much more of such objects because some are known from little fragments, others did not survive to our times at all. Stele of the Vultures is also not in perfect condition but surviving pieces allowed scholars to reconstruct most of it - including picture of the vultures eating bodies of the dead warriors which gave the name to monument (Nardo 2007:272). Important as well is that the iconography on one side of the stele reveal "historical" events - the battle - on the other side show gods interfering by fighting on the ruler's behalf, making the it half historical, half mythological source (Frankfort 1958:34). In the end of inscription Eannatum demand from king of Umma to tell the words of promise to six subsequent gods with interesting part:

[...] over the boundary territory of Ningirsu I shall not cross. To its levees and irrigation ditches I shall not make changes. Its steles (na-rú-a) I shall not smash to bits. On a day when I may cross over it, the great casting-net of Enlil, king of heaven and earth, by which I have sworn, upon Umma may it fall from the sky! ${ }^{1}$.

1 Translations of the Vulture Stele and Eannatum Boulder: "Sumerian Shakespeare" [online:] http://sumerianshakespeare.com/38801.html [19.02.2018]. 
Култура и/или наука

It is evident here that Sumerian term for stele is na-rú-a (narúa or narú) ${ }^{2}$. The word consists of two elements: na or $n a_{4}$ (Akkadian: $a b$ num) meaning: 'stone' and rú (Akkadian: banûm): 'to raise', 'to set' (Volk 1999:90-92). Even in Akkadian language and its later dialects: Babylonian and Assyrian this word is not translated as in the brackets, instead it stay in the form: narû (narûm), what literally mean in Sumerian 'raised stone' or 'set stone' and assure beyond any doubt that the custom is totally of Sumerian origins (Volk 1999:90).

In case of Mesopotamia any division to categories or types of stone objects or other classification is fully invention of modern scholars. All stone monuments with inscriptions were simply called na-rú-a (narúa or narú) including judiciary texts like land contracts - kudurru or law codes (Slanski 2000:95-96). Even more - whenever any inscription appealed to legal regulations the formula: awāt naruāim ('words of stele') was used, also on clay tablets (Veenhof 1995:1720-1721).

Stele of the Vultures mentions destruction of steles as act of war and later in time it is known that some of those monuments were stolen during military campaigns and moved to other states as a gift to gods, like it is the case with Victory Stele of Naram-Sin from ca. 2250 BCE which was taken from Sippar by Elamite ruler Shutruk-Nahhunta (ca. $1185-1155$ p.n.e.) who added to it inscription exactly saying so (Van De Mieroop 2007:184). Important to notice is also the fact that stone land giving contracts - $k u$ durru usually bear curse for those who will move it, destroy it or try to change the inscription - to protect the monument (Weeks 2004:31). So according to ancient Mesopotamians something set it stone is untouchable and protected by law and choice of this "eternal" raw material also speak for itself in region lacking it.

\section{China}

The Chinese were also often interested in their past and ancient culture. No wonder, then, that scientific studies of these investigations were written very early on. The Chinese tradition give Erya ("Approach-

2 The Pennsylvania Sumerian Dictionary [online:] http://psd.museum.upenn.edu/epsd/ nepsd-frame.html [19.02.2018]. 
ing Correctness") - allegedly created in the 11th century BCE - as the first written set of words and phrases ranked in 19 categories (Diringer 1972:110). Another catalog Juwen or Zhouwen was supposedly created by man named Zhou in the 9th century BCE. But the first historical and at the same time an official text of this kind, entitled San Qang, was written by $\mathrm{Li} \mathrm{Si}$ at the end of the 3rd century BCE during the reform of writing system. It contained 3300 characters (Diringer 1972:112). The most important text, however, derived from this literary tradition, which is also the oldest palaeographic dictionary in history, was Shuowen jiezi ("Notes on simple and analysis of complex characters") compiled by Xü Shen at the end of the 1st century CE (Künstler 1970:63). The time of completing the work can be estimated on the basis of a mention that it was submitted to Emperor Ho of the Han dynasty in 100 CE (Künstler 1970:65). The order of characters used by Xü Shen was based on 540 basic graphic elements, which are now called radicals (keys). It is the prototype of a modern arrangement of entries in Chinese dictionaries (Künstler 1970:66). The number of radicals was gradually reduced and the current variant with 214 radicals was achieved in the published in $1615 \mathrm{Zi} \mathrm{hui} \mathrm{("Lexicon} \mathrm{of}$ characters") by Mei Yingzuo. This system was reproduced in Kangxi zidian ("Kangxi Dictionary") published in 1716, thus acknowledging it as the only binding one (Künstler 1970:67).

Xü Shen created the term "six categories of characters" in his dictionary which is used by sinology to this day. Those classes of characters indicate their genesis. They are listed in the following order: 1) zhǐ shì - "pointing out concepts", 2) xiàng xíng - "similarity of shapes", 3) xíng shēng - "shape and sound", 4) huì yì - "combined meanings", 5) zhuăn zhù - "reversed comments" and 6) jiăjiè - "borrowed characters".

The first category - "pointing out concepts" - mainly includes abstract or ideographic characters, and the second - pictograms whose appearance is similar to the object they point to. The third class is ideographic-phonetic characters. In the fourth, the meaning of the whole sign can be read by determinatives, i.e. constituent elements belonging to the same semantic category. The fifth is not well understood, and the sixth is related to the phenomenon of homophony occurring in Chinese (Künstler 1970:67-71). Generally, this division can be simplified into three main groups: pictograms or perhaps more correctly simple charac- 
Култура и/или наука

ters, borrowed characters and ideographic-phonetic characters. The first of them have the form of one symbol and show objects, phenomena, as well as abstract concepts. The next group are the concepts for which no new, separate sign was invented, but an existing one with a similar pronunciation (homophony) was used instead. The last type are signs that can be otherwise called complex, because they are generally composed of two elements: a radical - key that performs the function of a semantic determinative and a phonetic element that indicates the pronunciation (Zemanek, Zemanek 2001).

Chinese scholars also studied ancient artefacts and often documented them. They were especially interested in bronze vessels that used to be a sign of prestige for the ancient and medieval Chinese. To obtain them were only two ways possible - either buy it from collectors or discover through excavations (Miller, Louis 2012:71-72). Because of that also fakes appeared and falsifying ancient bronzeware became profession in ancient China. The study on the bronze artefacts especially developed in the time of the Song dynasty (960-1279 CE). In that time several important scholars published (in print!) they works on that topic. In this way, a new "scientific discipline" called Kaogu xue - a "science of studying antiquity" was born in China (Shaughnessy 2005:23). The most famous example in this field is the book Kao gu tu ("Images of the study of antiquity"), written by Lü Dalin, who lived in the years 1046-1092. It contains detailed information of place of finding and later assembling 224 ancient bronze and jade items, as well as their exact drawings and measurements (Shaughnessy 2005:23). Another is Chong xiu Xuanhe bogutu ("Revised IIlustrated Catalogue of Xuanhe Profoundly Learned Antiquity") compiled in the years 1111-1125 and commissioned by emperor Huizong from Song Dynasty (1100-1125) himself which includes some 840 vessels drawings and rubbings (Clunas 2004:95; Trigger 2006:74-75). This publication was criticized by another scholar Hong Mai (1123-1202), who realized that some descriptions of ancient vessels from Han Dynasty were incorrect on the basis of examples he studied (Rudolph 1963:171). Ouyang Xiu (1007-1072) was also studying alleged ancient bronze and stone artifacts with archaic inscriptions on them. He published them as a collection of around 400 rubbings what makes him one of the first serious epigraphers (Clunas 2004:95). His continuator was Zhao Mingcheng (1081-1129) who 
published astounding 30-volume epigraphic work Jīn Shí Lù where he recorded the details of almost 2000 inscriptions from the past (Rudolph 1963:171; Clunas 2004:95; Trigger 2006:74). One of the latest scholars in this field in the imperial China was official Wáng Yiróng (1840-1900). The scholar was buying in the Beijing bazaars fragments of animal bones and turtle shells covered with mysterious engravings and he was the first person to recognize in 1899 that the so called "Dragon bones" discovered by locals actually bear early Chinese characters (Künstler 1970:39; Shaughnessy 2005:23).

But the tradition had much earlier roots and $5^{\text {th }}$ century text written by Xie Huilian is a proof for that. This poet described in detail the discovery of the tomb in Nanjing (Miller, Louis 2012:72).

When excavating a moat north of the wall of the Eastern Precinct, we had gone down to a depth of several yards when we found an ancient tomb. There had been no markers of a burial ground above, and for the sarcophagus no tiles had been used, only wood. In the sarcophagus were two coffins, exactly square, with no headpieces. As for the spirit vessels, we found twenty or so different kinds of ceramic, bronze and lacquer; most of these were of unusual form, and we were not able to identify them all. There were also more than twenty human figures made of wood, each of them three feet long. When the grave first opened, we could see that these were all human figures, but when we tapped them or poked them with something, they disintegrated into dust under our hands. On top of the coffin were more than a hundred "five-penny-weight" and coins. In the water were joints of sugarcane along with some plums pits and melon seeds, all of which floated up, none of them very rotten. The grave inscription had not survived, so we were unable to ascertain the date or age of the tomb. My lord commanded that those working on the wall rebury them on the eastern hill. And there, with pork and wine, we conducted a ceremony for the dead. Not knowing their names, whether they were near to us or far, we gave them the provisional title "The Obscure Master and Mistress". In the seventh year of the Yongjia Reign [430 CE] on the fourteenth day of the ninth month, Baron Zhu Lin... prepared ceremonial pork and wine and respectfully presented them to the spirits of the Obscure Master and Mistress [...] (Owen 1986:38-39). 
Култура и/или наука

Such astonishingly detailed description could be in a journal of modern archaeologist but with difference to it - the further, not quoted, fragment is actual poem, a prayer for the dead incorporating all the information about mysterious people of the past that founders could tell from examination of their tomb and remains (Miller, Louis 2012:72, 74).

\section{Final remarks}

From the presented material it is well visible for us that ancient "science" was not a systematic research but rather matter of prestige to know the deeds of the ancestors. The tradition was very important in all 3 great civilizations and people were looking to find a way to connect themselves with the past. The existence of writing gave them especially this opportunity. So wise men of those great "literate" civilizations were the first generations being able to read the words of long dead ancestors from hundred or even thousands of years in the past. The research and excavations on one hand served the basic human need for exploration and renovation or rebuilding of objects on the other was meant to immortalize the discoverer and save the memory of the dead. We have always rational and religious aspects of those investigations. Like Egyptian Khaemwaset who was hungry for knowledge but respectful for deceased and Egyptian belief in "name" (ran) according to which when dead person's name will be forgotten and all inscriptions recording it lost - only then that person is really dead. The idea is also a part of the already mentioned fictional story of "Khonsemhab and the Ghost". Restoration also could be done from double reasons like in the case of Great Sphinx and the Dream Stele - as a legitimization of the story in which there is proof of legal rights to the throne. The ancients Mesopotamians troubled themselves to write on material hard to obtain to preserve at least the information itself - like in the case temenu-foundation stones or curse someone who will move or change inscription, like in case of kudurru or some royal inscriptions. Chinese poet described in the very high detail the discovery of the tomb but also stopped to contemplate on the nameless dead and wrote a poem which is integral part of his "archaeological report". So there are 3 common reasons of analyzed actions in each of those 3 completely different cultures: 1 ) curiosity and prestige coming from the 
possession of ancient artefacts; 2) need of counseling from the ancestors about the customs and beliefs and 3) preservation of tradition and memory about the dead. There is no separation between sacrum and profanum here and excavation and research is not done out of purely rational scientific reasons. It cannot be because the world in which ancients had lived was not yet rational but still full of wonders.

\section{Sources and literature:}

Bator, Wiesław. Religia starożytnego Egiptu. Perspektywa religioznawcza. Kraków: Wydawnictwo Uniwersytetu Jagiellońskiego, 2012.

Beaulieu, Paul-Alain. "Antiquarianism and the Concern for the Past in the Neo-Babylonian Period". Bulletin of the Canadian Society for Mesopotamian Studies, 28 (1994): 37-42.

Bodine, J.J. "The Shabaka Stone: An Introduction". Studia Antiqua 7/I (Spring 2009): 1-21.

Breasted, James Henry. Ancient Records of Egypt, Volume II: The Eighteenth Dynasty. Chicago 1906.

Byrski, Łukasz. "Dusza uwieczniona w kamieniu - znaczenie imienia w wierzeniach staroegipskich". MASKA. Magazyn antropologiczno-społeczno-kulturowy, 16/2012: 1829.

Byrski, Łukasz. Funkcja inskrypcji monumentalnych w wybranych cywilizacjach starożytnych. unpublished M.A. thesis: Uniwersytet Jagielloński w Krakowie, 2014.

Clunas, Craig. Superfluous Things: Material Culture and Social Status in Early Modern China. Honolulu: University of Hawaii Press, 2004.

Diringer, David. Alfabet czyli Klucz do dziejów ludzkości. trans. W. Hensl. Warszawa: Państwowy Instytut Wydawniczy, 1972.

Frankfort, Henri. The Art and Architecture of the Ancient Orient. Harmondsworth, Middlesex: Penguin 1958.

Gardiner, Alan Henderson. Egyptian Grammar. Being an Introduction to the Study of Hieroglyphs. Oxford: Griffith Institute, 1979.

Gomaà, Farouk. Chaemwese: Sohn Ramses II unf Hoherpriester von Memphis. Wiesbaden: Otto Harrassowitz, 1973.

Künstler, Mieczysław Jerzy. Pismo chińskie. Warszawa: PWN 1970.

Lichtheim, Miriam. Ancient Egyptian Literature, Volume 1: The Old and Middle Kingdoms. Berkeley-Los Angeles: University of California Press, 1973.

Lichtheim, Miriam. Ancient Egyptian Literature, Volume 3: The Late Period. Berkeley-Los Angeles: University of California Press, 1980.

Manassa, Colleen. Imagining the Past: Historical Fiction in New Kingdom Egypt. New York: Oxford University Press, 2013. 
Култура и/или наука

Markiewicz, Tomasz. Egipskie piśmiennictwo Epoki Późnej. J. Lipińska (ed.). Tajemnice papirusów. Wrocław-Warszawa-Kraków: Zakład Narodowy im. Ossolińskich, 2005.

Mierzejewski, Antoni. Zapisane na glinie. Warszawa: Wydawnictwo Iskry, 1979.

Mierzejewski, Antoni. Sztuka starożytnego Wschodu I. Warszawa: Wydawnictwo Artystyczne i Filmowe, 1983.

Miller, Peter N., and François Louis. Antiquarianism and Intellectual Life in Europe and China, 1500-1800. Ann Arbor: University of Michigan Press, 2012.

Nardo, Don. The Greenhaven Encyclopedia of Ancient Mesopotamia. Detroit: Thomson/ Gale, 2007.

Nemet-Nejat, Karen Rhea. Daily Life in Ancient Mesopotamia. Westport-London: Greenwood Publishing Group, 1998.

Owen, Stephen. Rememberances: The Experience of the Past in Classical Chinese Literature. Cambridge: Harvard University Press, 1986.

Pinch, Geraldine. Handbook of Egyptian Mythology. Santa Barbara-Denver-Oxford: ABCCLIO, 2002.

Reiner, Erica. Your Thwarts in Pieces, Your Mooring Rope Cut: Poetry from Babylonia and Assyria. Ann Arbor: Michigan Slavic Publications, 1985.

Rudolph, R.C. "Preliminary Notes on Sung Archaeology". The Journal of Asian Studies (Volume 22, Number 2, 1963): 169-177.

Schneider, Thomas. Leksykon faraonów. trans. R. Darda, E. Jeleń, Z. Pisz. WarszawaKraków: PWN, 2001.

Shaughnessy, Edward Louis. Chiny. Życie, legendy i sztuka. trans. T. Jurewicz. Warszawa: National Geographic Society, 2005.

Slanski, Kathryn E. "Classification, Historiography and Monumental Authority: The Babylonian Entitlement "narûs (kudurrus)"”". Journal of Cuneiform Studies, Vol. 52 (2000): 95-96.

Trigger, Bruce G. A History of Archaeological Thought, Second Edition. New York: Cambridge University Press, 2006.

Van de Mieroop, Marc. The Eastern Mediterranean in the Age of Ramesses II. Oxford: Blackwell Publishing, 2007.

Veenhof, Klaas Roelof. "In Accordance with the Words of the Stele: Evidence for Old Assyrian Legislation". Chicago-Kent Law Review,Volume 70, Issue 4 (June 1995): 1720-1721.

Volk, Konrad. A Sumerian Reader. Roma: Editrice Pontificio Instituto Biblico, 1999.

Vygus, Mark. Middle Egyptian Dictionary. updated in 2012. Web: http://www.pyramidtextsonline.com/documents/VygusDictionaryApril2012.pdf. 27.05.2017.

Walker, C.B.F. "Cuneiform”. J. T. Hooker (ed.). Reading the Past: Ancient Writing from Cuneiform to the Alphabet. Berkeley-Los Angeles: University of California Press/British Museum, 1990.

Weeks, Noel. Admonition and Curse: The Ancient Near Eastern Treaty/Covenant Form as a Problem in Inter-Cultural Relationships. London-New York: T\&T Clark International, 2004.

Wilson, Penelope. Hieroglyphs. A Very Short Introduction. New York: Oxford University Press, 2004. 
Zemanek, Adina and Bogdan S. Zemanek. „Chińszczyzna”. Wiedza i Życie 5/2001. Web: http://archiwum.wiz.pl/2001/01050800.asp. 19.02.2018.

"Translations of the Vulture Stele and Eannatum Boulder": Sumerian Shakespeare. Web: http://sumerianshakespeare.com/38801.html. 19.02.2018.

The Pennsy/vania Sumerian Dictionary. Web: http://psd.museum.upenn.edu/epsd/ nepsd-frame.html. 19.02.2018.

\section{Мр Лукаш Бирски}

Јагиелонски универзитет у Кракову, Пољска

Филозофски факултет

Институт за научно истраживање религија

\section{ДРЕВНЕ НАУКЕ: РАЗУМЕВАЊЕ ИСТОРИЈЕ И ЈЕЗИКА У ДРЕВНИМ ЦИВИЛИЗАЦИЈАМА}

\section{Садржај}

Када размишљамо о научним сазнањима у древним временима, обично га одбацујемо као стварну "науку" због недостатка модерне методологије у њој. Изненађујуће за данашње друштво неке од раних сложених култура нису биле толико далеко од нашег у потрази за знањем и разумевањем њихове историје и језика и манипулисати њима за сврху. Понекад су чак створили “научне дисциплине” веома близу савремених класификација, али са веома различитим и неочекиваним циљевима пред нама. У Месопотамији Акађани који су наследили писмену културу Сумераца су се највероватније суочили са проблемом превођења са потпуно другачијег језика у првобитне рјечнике и гледајући у разлике између својих речи и оних других људи. Древни Кинези су се питали о пореклу писаних знакова и старих предмета случајно пронађених у неким земљаним радовима. Још више - неки од њих су фалсификовали ове артефакте да би их продали необзирним колекционарима. Древни Египћани су вршили систематске рестаурације споменика предака и очувања писаних текстова. Овај рад ће испитати шта све то говори о тим културама, како су те “науке" утицале на њих и како је ова интеракција у савременој култури другачија.

Кључне речи: античко време, Месопотамија, Кина, Египат, историја, филологија, археологија, фалсификовање, рестаурација, наука 